\title{
Challenges for the implementation of the chain of custody for rape victims in the Federal District
}

\author{
Desafios para implantação da cadeia de custódia para as vítimas de estupro no Distrito Federal \\ Desafíos para implantación de la cadena de custodia para víctimas de violación en el Distrito Federal
}

\author{
Alessandra Arrais ${ }^{1,2,3}$ (1) \\ Elen Carioca Zerbini ${ }^{1,4}$ (D)
}

Fernanda Schieber Saúde Vilas Boas de Oliveira Jota ${ }^{1,3}$ (D)

Renata Rodrigues de Melo Almeida ${ }^{3}$ (D) Arlete Rodrigues Chagas da Costa ${ }^{2,3}$ (1) Katiane Tavares da Silva2,3 (D)

1. Escola Superior de Ciências da Saúde, Programa de Mestrado Profissional. Brasília, DF, Brasil.

2. Secretaria de Saúde do Distrito Federal. Brasília, DF, Brasil.

3. Universidade de Brasília, Departamento de Psicologia. Brasília, DF, Brasil.

4. Escola de Profissionais da Parentalidade. Brasília, DF, Brasil.
Corresponding author:

Alessandra da Rocha Arrais.

E-mail: alearrais@gmail.com

Submitted on 03/28/2019.

Accepted on 07/30/2019.

DOI: 10.1590/2177-9465-EAN-2019-0101

\section{Abstract}

Chain of Custody implies adequate collection, recording, and storage of the vestige of sexual violence, guaranteeing the reliability of the material that will be forwarded as expert evidence. Its implementation in the Unified Health System has faced challenges. Objective: To know the attendance to victims of sexual violence in the public maternity of Federal District and evaluate the knowledge of the team about the legislation on a chain of custody. Method: Cross-sectional, quantitative, and descriptive study with 134 medical and nursing professionals working in the obstetric emergency, who answered a questionnaire, submitted to descriptive statistical analysis and the Qui-Square Test. Results: Of the $78.95 \%$ of professionals who reported attending to victims of sexual violence, $25.71 \%$ consulted in 10 minutes, and $14.18 \%$ received specific training. The situational diagnosis reveals that the care is superficial, centered on medical issues, and the collection of vestiges is non-existent. Conclusion and implications to nursing practice: A generalized change of posture is necessary so that it is possible to implant the chain of custody in the maternity studied. It is essential to develop care beyond medical issues, and which includes forensics. It is suggested a collaborative action between physicians and nurses, with nursing as the epicenter of this process.

Keywords: Sex Offenses; Custodial Care; User Embracement; Unified Health System.

\section{Resumo}

A Cadeia de Custódia implica no adequado processo de coleta, registro e armazenagem do vestígio da violência sexual, garantindo a confiabilidade do material que será encaminhado como prova pericial. Sua instalação no Sistema Único de Saúde tem enfrentado desafios. Objetivos: Conhecer o atendimento à vítima de violência sexual em maternidade pública do DF e avaliar o conhecimento da equipe acerca da legislação sobre cadeia de custódia. Método: Estudo transversal, quantitativo e descritivo, com 134 profissionais de medicina e enfermagem que atuam na emergência obstétrica, que responderam a um questionário, submetido à análise estatística descritiva e o Teste Qui-Quadrado. Resultados: Dentre os $78,95 \%$ dos profissionais que afirmaram atender vítimas de violência sexual, $25,71 \%$ as consultam em 10 minutos e $14.18 \%$ receberam capacitação específica. $O$ diagnóstico situacional revela que o atendimento é superficial, centrado em questões médicas e a coleta de vestígios é inexistente. Conclusão e implicações para a prática de enfermagem: Uma mudança generalizada de postura é necessária para que seja possível implantar a cadeia de custódia na maternidade estudada. É fundamental desenvolver um o atendimento para além de questões médicas, e que inclua questões periciais. Sugere-se uma atuação colaborativa entre médicos e enfermeiros, tendo a enfermagem como epicentro desse processo.

Palavras-chave: Delitos Sexuais; Assistência de Custódia; Acolhimento; Sistema Único de Saúde.

\section{Resumen}

La Cadena de Custodia implica el adecuado proceso de recolección, registro y almacenamiento del vestigio de la violencia sexual, garantizando confiabilidad al material encaminado como prueba pericial. Su instalación en el Sistema Unico de Salud ha enfrentado desafíos. Objetivos: Conocer la atención a la víctima de violencia sexual en maternidad pública del Distrito Federal y evaluar el conocimiento del equipo acerca de la legislación sobre cadena de custodia. Método: Estudio transversal, cuantitativo y descriptivo, con 134 profesionales de medicina y enfermería actuantes en la emergencia obstétrica, que respondieron un cuestionario, sometido al análisis estadístico descriptivo y al Test Qui-Cuadrado. Resultados: Entre el $78,95 \%$ de los profesionales que afirmaron atender a víctimas de violación, 25,71\% las consultan en 10 minutos y $14.18 \%$ recibieron capacitación específica. El diagnóstico situacional revela que la atención es superficial, centrada en cuestiones médicas y la recolección de vestigios es inexistente. Conclusión e implicaciones para la práctica de enfermería: Un cambio generalizado de postura es necesario para posibilitar la implantación de la cadena de custodia en la maternidad estudiada. Es fundamental desarrollar una atención más allá de cuestiones médicas y que incluya cuestiones periciales. Se sugiere una actuación colaborativa entre médicos y enfermeros, teniendo la enfermería como epicentro de ese proceso.

Palabras clave: Delitos Sexuales; Cuidado en Custodia; Acogimiento; Unified Health System. 


\section{INTRODUCTION}

One in six women suffer some form of violence worldwide, usually perpetrated by a husband or boyfriend; reveals a study conducted in ten countries, including Brazil, by the World Health Organization. ${ }^{1}$ This shows that women are more exposed to violence in the private sphere rather than in the public, ${ }^{1}$ especially when they are still children. It is estimated that around 120 million female children and adolescents worldwide have been sexually abused. ${ }^{2}$ In Brazil, sexual violence is the main cause of care in the violence referral services, and among children, female correspond to $60 \%$ of all reported and confirmed cases. In the Brazilian Northeast, the majority of victims of sexual violence in children and adolescents were female (79\%). ${ }^{2}$

The asymmetrical relationship between men and women in patriarchal domination gives rise to what is conceptualized as gender violence, which is part of a universe in which inequality and oppression prevail. ${ }^{1}$ Gender violence is mainly targeted at women and girls, as mentioned above, as well as being a public health issue and a violation of human rights. ${ }^{1}$ Violence causes the death, mostly, of women aged between 15 to 44 years old, which is more significant than deaths from malaria, cancer, accidents and wars. ${ }^{3}$

Sexual violence is an act that breaks out in the life of a child or a woman and pervades and mars all their ideals of life. ${ }^{3}$ As much as we are aware that sexual violence is something that actually exists, in Brazil, in general, no woman really believes that this can happen to her. No woman, even less a child, prepares to live such an experience, or think it might happen to her. But while this is not part of the theoretical and factual world of almost all women, unfortunately, the Map of Violence data shows that it does happen more and more often than might be supposed. ${ }^{3}$

The difficulties found in the Brazilian context, according to the literature, do not differ from the world reality. Are factors that make it difficult for professionals to identify situations of this nature: the silence presented by women and children, the lack of training of the professionals themselves, the lack of knowledge of community resources and the proper procedures for the progress of the case, the lack of interest of professionals, the theme being difficult to approach, the fear of involvement, the feeling of helplessness in the face of the situation, institutional barriers, among others. ${ }^{4}$ In daily work, such barriers are noticeable and make it difficult to adopt effective actions to confront violence. ${ }^{4}$

\section{LITERATURE REVIEW}

Most health professionals prefer to deal with diseases, since the interventions are already established by biomedicine. ${ }^{5}$ Others do not recognize violence as a demand for public health. ${ }^{6}$ In contrast, a study conducted with physicians and nurses from the medical clinic/gynecology sector in Ribeirão Preto/SP, showed that $93.2 \%$ of professionals recognize their responsibility as health professionals to encourage women to break from the situation of violence, $96.8 \%$ believe that other care possibilities should be provided, $92.2 \%$ argue that they should be alert to signs of violence. Most of them, $93.7 \%$, argued that professionals should not only take care of injuries, without questioning the situation and guiding. ${ }^{6}$ The expanded conception of health allows a comprehensive and welcoming service, interested in the resolution of the demand.

The expanded look on the health of women and children allows professionals to identify situations during care that may signal the occurrence of violence such as somatization, unfounded complaints, discomfort, depression, pain in the genitalia or during sexual intercourse, among others. ${ }^{7}$ Professional practice guided by the expanded concept of health does not require activities that go beyond the clinic space and the deciphering of reality beyond what is mentioned in the immediate demands. However, professionals generally do not use specific instruments to identify violence, nor to survey the needs of children ${ }^{2}$ and women. ${ }^{8}$ It is necessary to consider whether universities are preparing health professionals with this perspective of comprehensive care of the subject or if they are still promoting training focused only on diseases and do not include noncommunicable diseases, where sexual violence cases are included. ${ }^{7}$

Law Nr. 12.845/2013 provides for the compulsory and comprehensive care of people in situations of sexual violence. This Law is a milestone in the area of violence, because in addition to ensuring emergency and comprehensive care to rape victims, whether women, children, adolescents and the elderly, it provides that this care is multidisciplinary, with participation in the emergency team not only of the physician and nurse, but also psychologist and social worker. ${ }^{9}$

In addition to this law, Interministerial Ordinance No. $288 / 2015$, signed between the Ministry of Justice and the Ministry of Health, establishes guidelines for the organization and integration of care for victims of sexual violence by public safety professionals and health professionals of the Unified Health System (UHS) regarding the humanization of care to victims and the recording of information and collection of vestiges within the UHS. ${ }^{10}$

Interministerial Ordinance No. $288 / 2015$ also provides that emergency care for children and women who are victims of sexual violence should be carried out an own trained team, which should be composed of a gynecologist, nurse, psychologist and social worker. ${ }^{10}$ Its main objective is to avoid a pilgrimage of victims to health and justice agencies soon after the event of violence, thus reducing the trauma and effects generated and aggravated with the process of revictimization. ${ }^{10}$ 
In this context that involves the psychological care and social work, in addition to the medical and nursing activities, is glimpsed the possibility of women or children having collected the genetic material related to violence already in health care, in a hospital environment, with proper storage in the hospital itself, through the implementation of the Chain of Custody. ${ }^{10}$

The Chain of Custody implies the proper process of collection, registration and storage of biological material that remains as a trace of sexual violence, thus ensuring the reliability of the material that will be referred for examination as expert evidence. The Technical Standard: Humanized Care for People in Situation of Sexual Violence with registration of information and collection of vestiges, published by the Ministry of Health in 2015, brings with it the entire protocol for the safe performance of this service. It lists the materials and structures required for its implementation. ${ }^{10}$ There is also the need to train professionals, carefully selected, to be assigned to be part of the teams responsible for assisting victims who have suffered violence, especially when they are children and women. ${ }^{11,12}$

The process of the installing of chains of custody within UHS is planned for the whole Brazil, and in the Federal District (FD), at first, the chain of custody would be installed in five pilot public hospitals, including a maternity ward, which is a reference for high risk pregnancies in the FD and the target of this article. Considering that this is one of the hospitals covered by this project, it is understood that it is of fundamental importance that a research on this theme occurs. The focus of this article was to know the service to the victim of sexual violence in a public maternity hospital of the Federal District and to analyze the perceptions of the team about the chain of custody legislation. Therefore, it is necessary to characterize the stages of care for victims of sexual violence in the obstetric emergency of maternity, as well as to verify if the professionals received specific training for this type of care and if they know the chain of custody law in this service.

\section{METHOD}

This is a cross-sectional study of a quantitative and descriptive nature. ${ }^{13}$ The study site was the gynecological/ obstetric emergency of a public maternity hospital in the Federal District. The sample was formed by of convenience and consisted of 65 gynecologists/obstetricians staffs, 23 nurses and 95 nursing technicians, as well as some residents from both areas. To be included in the research, all should work in the obstetric emergency of the referred maternity and not be away from work during collection. Questionnaires were made available to the entire population, and 134 professionals returned the instruments answered. A closed and self-applied anonymous questionnaire containing 14 questions was answered and tested by the research team, which was answered within 10 minutes on average.
Initially, an instrument test was performed with one member from each of the study's professional categories, to approximate the research field and adequacy of the instruments and collection procedures. Subsequent to the analysis of the instrument test data, definitive data collection began. The professionals were approached by the researchers during working hours and were invited to participate in the research and sign the Informed Consent Form. Then, they received the questionnaire and an envelope that they returned sealed and unidentified, with the questionnaire answered, to preserve the anonymity of the participants and minimize biases by the possibility of identifying them. For data analysis was used descriptive statistics, using absolute and relative frequencies for the variables studied to characterize the population studied and for the rest of the quantitative data were used the Chi-Square Test with a significance level of $5 \%$. The program used for data processing was R 3.5 .

It should be clarified that this study was approved by the Research Ethics Committee, under Opinion No. 1,226,439, of September 14, 2015, No. CAAE 48229015.1.0000.5553. This research followed the ethical principles of Resolution 466/12 of the National Health Council, and was in line with the principles of the current Code of Ethics of Nursing Professionals.

\section{RESULTS}

\section{Characterization of research participants}

A total of 134 professionals were participants, 114 female, corresponding to $85.07 \%$ of the total participants, and 20 male, representing $14.93 \%$. The professional categories had the following composition: 20 were nurses (14.93\%), 37 physicians $(27.61 \%)$, 2 nurse residents (1.49\%), 13 physician residents $(9.7 \%)$ and 62 nursing technicians $(46.27 \%)$. The age range of the participants was: up to 25 years, 5 (3.76\%); from 25 to 35 years old, $48(36.09 \%)$; from 35 to 45 years old, 40 professionals (30.08\%), from 45 to 60 years old, 36 (27.07\%), over 60 years old, 4 professionals $(3.01 \%)$. Regarding the level of education, was found: undergraduate 35 (28.46), specialization $67(54.47 \%)$, master's degree 8 (6.5\%), physicianate $2(1.63 \%)$, and other $11(8.94 \%)$.

Regarding the time of exercise of their duties at SES/FD: 1 year or less, 12 (8.96\%); from 1 to 5 years, 40 (29.85\%), from 5 to 10 years, 22 (16.42\%); from 10 to 20 years, 37 (27.61), over 20 years, $23(17.16 \%)$. However, as for the professional experience, it was observed that 122 professionals, $91.04 \%$ of the total participants, have more than 10 years of professional experience at SES/FD, indicating that the analyzed group tends to have extensive experience of subjects related to the provision of health services. Regarding the training received by professionals focused on caring for victims of sexual violence: 115 (85.82\%) of the professionals answered that they did not receive any kind of training, $19(14.18 \%)$ answered that they received some kind of training. 
Of the percentage of $85.82 \%$, regarding participants who received no training, when faced with the question: do you attend women victims of sexual violence? $28(21.5 \%)$ professionals answered that they did not attend, and 105 (78.95\%) answered that they did. That is, although most have not received any specific training to assist victims of violence, most have to provide this type of care in their practice in the Emergency. It is noteworthy that although $78.95 \%$ of professionals attend victims of sexual violence, both children and women, $85.82 \%$ of professionals did not receive any training for this type of care. This is alarming data, since it can be concluded that there is little preparation for care of victims in the health network of SES/FD, especially when they are infants. Even those who have never received specific training for this purpose are obliged to serve this clientele in their daily work.

Despite these results, when asked if the professional feels comfortable attending women victims of sexual violence, 75 professionals answered no $(56.82 \%)$ and 57 (43.18\%) answered yes. Figure 1 presents this result by professional category, showing that physicians are the ones who say they are most comfortable and nursing technicians the least comfortable.

Figure 1. Distribuition by professional category regarding comfort $x$ discomfort in attending victims of sexual violence in the emergency.

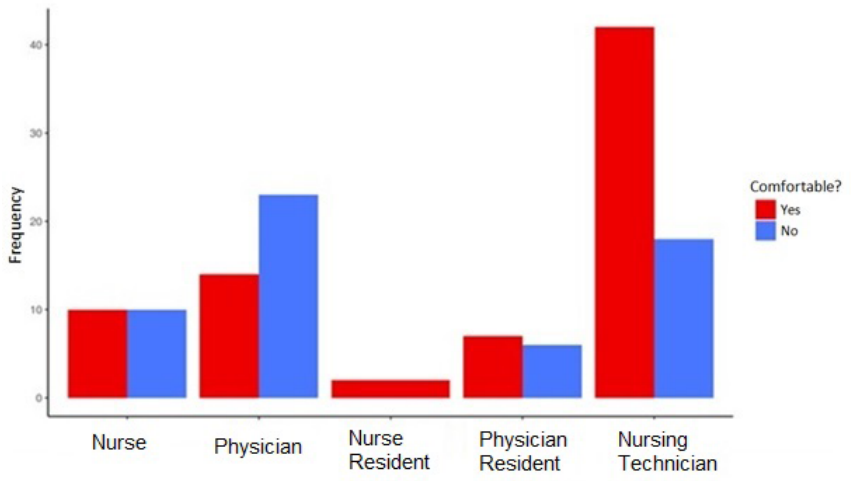

Regarding the question "do you think it is important to receive continued training for the care of women and children victims of sexual violence", 3 (or $2.26 \%$ ) of the professionals answered no, and $130(97.74 \%)$ answered that they considered the training important. Therefore, there is a clear recognition of the need for specific training regarding the care of victims of sexual violence in the sample studied and also suggests a repressed demand regarding the support to qualify their professional performance.

Contradictorily, it is observed that $97.74 \%$ of professionals consider it important to receive continuous training to assist women and children victims of sexual violence. This data suggests that the failure to receive training by $85.82 \%$ of professionals probably does not result from the fact that these professionals do not consider the training in question important.

\section{Characterization of care for victims of sexual violence in the hospital surveyed}

Regarding the accountability of the stages of care for victims of sexual violence, considering the answers yes or no: 74 (63.79\%) make the Reception and $16(13.09 \%)$ the Risk Rating; $87(75 \%)$ Give medication; $48(41.38 \%)$ perform the filling of the compulsory notifications; 68 (58.62\%) answered no and 48 (41.38\%) answered yes. Prescribing medication, $72(62.07 \%)$ no and $44(37.93 \%)$ yes. Clinical attendance, 81 (69.83\%) no and 35 (30.17\%) yes. Echography, $114(98.28 \%)$ no and $2(1.72 \%)$ yes. To discharge, 98 (84.48\%) no and 18 (15.52\%) yes.

Table 1 shows the cross frequencies and the result of the $\mathrm{X}^{2}$ test between the profession and the care stage, analyzing the $p$-values. It is noticed that eight types of care are significant with the profession, the test does not tell which category would be more significant, being necessary to observe through the frequencies and why.

As for the question: "how long, on average, does your care for victims of sexual violence last?" Between 30 and 60 minutes, 35 (33.33\%), up to 10 minutes, $27(25.71 \%)$, between 20 and 30 minutes, 24 (22.86\%), between 10 and 20 minutes, 14 (13, $33 \%$ ), and more than 60 minutes, 5 (4.76\%). Table 2 shows the cross frequencies and the result of the $\chi^{2}$ test between profession and attendance time, analyzing the $p$-values.

It can be seen in Table 2 that medical and nursing care in cases of sexual violence are the longest (most lasting about 30 to 60 minutes), which reinforces the importance and need for appropriate and continued training to provide adequate care, given the complexity involved in the context, as simple care is usually faster; the more complex the situation, or when the victim is a child, the longer the care.

Concerning the question: "Do you know Law No. 12.845 of 2013 governing uninterrupted multidisciplinary care for victims of sexual violence in hospital emergencies?" 100 (79.37\%) no, and $26(20.63 \%)$ yes.

As for the question: "Do you know Interministerial Ordinance No. 288 of 2015 governing the installation of Chains of Custody in hospital emergencies?" 121 (94.53\%) no, and 7 (5.47\%) yes.

Regarding the question: "Do you consider that the presence of a psychologist and social worker in the care team for the victim of sexual violence would improve the quality of the service provided?" 125 (98.43\%) yes, especially for children, and 2 $(1.57 \%)$ no.

\section{DISCUSSION}

Health care in Brazil faces several difficulties ${ }^{14}$ with few initiatives aimed at implementing effective methodologies to increase the quality of services provided. ${ }^{14}$ Among some 
Table 1. Distribution by professional category, according to the type of assistance to victims of sexual violence in the emergency.

\begin{tabular}{lcccccccc}
\hline & Nurse & Physician & $\begin{array}{c}\text { Physician } \\
\text { Resident }\end{array}$ & $\begin{array}{c}\text { Nurse } \\
\text { Resident }\end{array}$ & $\begin{array}{c}\text { Nursing } \\
\text { technician }\end{array}$ & Total & P value & Sig \\
\hline Reception & 14 & 12 & 2 & 3 & 43 & 74 & 0.000 & $*$ \\
Risk rating & 10 & 1 & 1 & 1 & 3 & 16 & 0.000 & $*$ \\
Give medication & 16 & 3 & 2 & 1 & 7 & 29 & 0.000 & $*$ \\
$\begin{array}{l}\text { Perform the filling of the } \\
\text { Compulsory Notification }\end{array}$ & 10 & 26 & 1 & 11 & 0 & 48 & 0.000 & $*$ \\
Prescribing medication & 0 & 32 & 0 & 12 & 0 & 44 & 0.000 & $*$ \\
\hline Clinical care & 0 & 26 & 0 & 9 & 0 & 35 & 0.000 & $*$ \\
Perform Echography & 0 & 1 & 0 & 0 & 1 & 2 & 0.926 & $*$ \\
\hline Discharge & 0 & 13 & 0 & 5 & 0 & 18 & 0.000 & $*$ \\
\hline
\end{tabular}

Table 2. Distribution by professional category, regarding the attendance time to victims of sexual violence in the emergency.

\begin{tabular}{|c|c|c|c|c|c|c|c|c|c|c|c|c|c|}
\hline & $\begin{array}{l}\text { Up } \\
\text { to } 10 \\
\text { min }\end{array}$ & $\%$ & $\begin{array}{c}\text { Between } \\
10 \text { and } 20 \\
\text { minutes }\end{array}$ & $\%$ & $\begin{array}{c}\text { Between } \\
20 \text { and } 30 \\
\text { minutes }\end{array}$ & $\%$ & $\begin{array}{c}\text { Between } \\
30 \text { and } 60 \\
\text { minutes }\end{array}$ & $\%$ & $\begin{array}{c}\text { More } \\
\text { than } \\
60 \mathrm{~min}\end{array}$ & $\%$ & Total & $\%$ & $\begin{array}{c}P \\
\text { value }\end{array}$ \\
\hline Nurse & 1 & 0.95 & 0 & 0 & 3 & 2.86 & 11 & 10.48 & 3 & 2.86 & 18 & 17.14 & 0 \\
\hline Physician & 0 & 0 & 6 & 5.71 & 12 & 11.43 & 18 & 17.14 & 0 & 0 & 36 & 34.29 & \\
\hline Nurse Resident & 0 & 0 & 0 & 0 & 0 & 0 & 2 & 1.9 & 0 & 0 & 2 & 1.9 & \\
\hline Physician Resident & 0 & 0 & 3 & 2.86 & 6 & 5.71 & 1 & 0.95 & 0 & 0 & 10 & 9.52 & \\
\hline Nursing technician & 26 & 24.76 & 5 & 4.76 & 3 & 2.86 & 3 & 2.86 & 2 & 1.9 & 39 & 37.14 & \\
\hline Total & 27 & 25.71 & 14 & 13.33 & 24 & 22.86 & 35 & 33.33 & 5 & 4.76 & 105 & 100 & \\
\hline
\end{tabular}

measures, we highlight the implementation of an integrated care network for women and children in situations of sexual violence, as recommended by Law 12.845 , which provides for the compulsory and comprehensive care of people in situations of sexual violence. ${ }^{9}$

According to the guidelines of the National Policy for the Reduction of Morbidity and Mortality by Accidents and Violence of $2001,{ }^{16}$ people in situations of violence have the right to be welcomed, oriented, assisted and referred, when necessary, to specialized services. ${ }^{15}$ In order to this care to occur in its entirety, it is essential that professionals know the current laws, as well as the care manuals recommended by the Ministry of Health and are properly trained. ${ }^{16}$

However, the present study draws attention to the large number of professionals who work directly in the care of these victims, but are unaware of the technical norms and clinical protocols that support women victims of sexual violence in hospital emergencies, including the legislation of the Chain of Custody. ${ }^{10}$
This aspect constitutes a challenge to be faced for the implementation of the chain of custody, since the lack of knowledge, the professionals' discomfort in the care of the victim of sexual violence, as well as the structural weaknesses of the system itself are aggravating factors that do not favor the success of this service, generating negative consequences that affect the lives of victims. ${ }^{16,17}$

It was noted that, regarding the way to address psychopathological issues that may affect this type of patient, there is no specific training of professionals to care for the victim of sexual violence, especially when they are children. There is also a lack of awareness of the impacts of a superficial emergency reception on the future development of the case. The more prepared the emergency care professional is for the child, the greater the possibility of reducing the impacts of this violent experience and preventing future emotional trauma and mental illness. ${ }^{16}$

The study revealed that $78.95 \%$ of professionals treat victims of sexual violence, but only $14.18 \%$ of them received any specific training. However, $97.74 \%$ of these professionals 
consider it important to receive continued training to assist victims of sexual violence. This data draws attention to the need for training of all professionals involved in care, ${ }^{12}$ including physicians, psychologists, nurses, nursing technicians and social workers. Ideally, only adequately trained professionals should be assigned to care for children and women who have suffered sexual violence, they should be carefully chosen, voluntarily participate in training and be part of the team. ${ }^{11,18}$

It is essential to insert continuing education programs involving the theme, as well as to carry out extension projects and/or research in line with the services ${ }^{19}$ involving health professionals. It is necessary to prepare them for the understanding of violence in its complexity, overcoming pathophysiological aspects, as well as for the clarification of the legislation, in order to overcome their resistances and face the barriers encountered during the care of these victims. ${ }^{17}$

The result of inadequate assistance and the lack of support from public agencies can lead to additional consequences, including the effects of over victimization or secondary victimization. Therefore, it is essential that there are services which attend these women efficiently, warmly, in an environment capable of intervening and minimizing the effects caused by violence. $^{12}$

Regarding the average duration of care, it was noticed that it varies according to the attributions exercised by professionals in the execution of the procedures recommended by the Ministry of Health. This includes measures for prevention, emergency, follow-up, rehabilitation, treatment of possible injuries and impacts resulting from sexual violence on physical and psychological health, which require different approaches for each profession. ${ }^{22}$ As for the stages of care for victims of sexual violence, these should be provided by the institutions whenever necessary. Data that needs to be highlighted, is that 27 professionals $(25.71 \%)$ stated that they treat a victim in just 10 minutes. It is essential to be clear that violence is a complex and multifaceted phenomenon, and that the break with situations of this nature is procedural and gradual. Each woman has her time to ask for help and meet the conditions necessary to break the cycle of violence..$^{19}$

The perception of health professionals about the occurrence of violence directly impacts the actions developed. Professionals can act to strengthen the project against hegemony or the opposite. Compartmentalized and dissociated interventions from discussions and multiprofessional interventions restrict the possibilities of coping. Reception and qualified listening are forms of care, besides being expressly mentioned in Law $12.845 .{ }^{9}$

The study also showed that for $98.43 \%$ of the participants, the presence of psychologist and social worker in the care team for victims of sexual violence would contribute to the improvement of the quality of care provided. This multidisciplinary approach would minimize the suffering and difficulties that may interfere with adherence to the service, on decisions to be made regarding violence, eventual pregnancy and the resumption of daily life; in addition, it broadens each professional's view of violence while ensuring greater quality in victim care. ${ }^{20}$

In summary, the results reveal that care for victims of sexual violence in the researched maternity hospital is done in a fragmented manner. When these patients enter the gynecological/obstetric emergency department, they are attended by the medical and nursing professionals who, in their majority, do not have training for this type of demand. This can lead to poor reception and loss of follow-up regarding emergency prophylaxis for sexually transmitted diseases (STDs). ${ }^{21}$ Studies ${ }^{21}$ indicate that there is no good adherence to 21-day chemoprophylactic follow-up against STDs, such as that performed with victims of sexual violence in Campinas-SP, which showed that only $12.20 \%$ of victims surveyed completed the proposed care. ${ }^{21}$

Thus, the care shows itself superficial in relation to the complexity of the demand, without proceeding with the collection of vestiges, chain of custody (nonexistent) and adequate description of injuries that may support expert examinations..$^{10}$ It is essential to develop a service of excellence that involves the comprehensive and globalized care of victims of sexual violence, and a collaborative action between physicians and nurses for this public, in view of the known repercussion on the quality of care, performed in this way.

However, speaking of this type of work we agree with Waldow, ${ }^{22}$ who suggests placing the nurse at the epicenter of this collaborative process, although this type of work should count on the cooperation of all. ${ }^{22}$ Therefore, care needs to focus beyond medical issues, on expert issues, as it is known that many patients who are victims of sexual violence go to emergency medical services, but not to the Institute of Forensic Medicine (IFM) to perform the forensic medical examination.

Finally, based on the data obtained, it is necessary to invest in the training of teams and professionals responsible for emergency care provided to children and women in situations of sexual violence, especially nursing professionals, who are usually the first to have contact with the victims. It is essential to include in the work routine continuing education, training, technical bases for care, including the complexity of the phenomenon of violence, knowledge of laws and protocols and standards that guide and ensure proper care according to the life cycle.

\section{FINAL CONSIDERATIONS AND IMPLICATIONS TO PRACTICE}

Considering the proposed objectives and the results found in this research, it is concluded that the assistance to women victims of sexual violence in the emergency of the studied maternity is superficial, centered on medical issues and the collection of vestiges is nonexistent. 
It is necessary a generalized change of attitude among the studied team, so that it is possible to implement the chain of custody within the UHS, in the researched maternity, especially regarding the care of these victims. To this end, we suggest some actions that need to be developed, as well as goals that need to be achieved, for the proper functioning of the service, considering the technical standards and objectives of the chain of custody: training with the preparation of courses, classes and lectures for residents, involving them in the care of victims of sexual violence; refresher and training courses for medical and nursing professionals working in the hospital's obstetric emergency (updating, addressing non-medical issues, discussing professional accountability in urgent situations, among others); proposing technical-scientific meetings to discuss cases of women and children in situations of sexual violence who sought care at the maternal and child hospital.

Since this study is limited to data collection with medical and nursing professionals, further studies with a larger sample are suggested, including other specialties such as psychology and social work that also deal with rape victims in the referred maternity ward. Qualitative studies would also be useful to understand the reasons for the professionals' discomfort to attend to the victims of sexual violence, the obstacles to the accomplishment of the continuing education in this subject and the obstacles and possibilities for the implantation of the chain of custody in the referred maternity.

Sexual violence, recognized as a public health problem, requires a systematized, articulated and integrated approach among different sectors. ${ }^{23}$ In this sense, it requires a continuous effort in sensitizing professionals, especially in nursing, as well as the involvement and support of management in this process. ${ }^{23}$ Thus, the commitment of the management and professionals of both of health and of security and justice institutions involved in the investigation of crimes $^{23}$ is fundamental to enable the implementation of the chain of custody in the FD.

\section{ACKNOWLEDGMENT}

To Dr. João Villela (Director of the Maternal and Children's Hospital of Brasília), to Professor Aline Mizusaki Imoto (Higher School of Health Sciences), to Physician Alexandre Pavan and to Psychologist Cristina Moreira Azevedo, both of the State Secretariat of Health of the Federal District, who contributed in different ways to the development of the study and elaboration of this article.

\section{FINANCIAL SUPPORT}

State Department of Health of the Federal District. Health Sciences Teaching and Research Foundation (FEPECS) Scientific or technological research projects number 04/2016.

\section{REFERENCES}

1. World Health Organization (WHO). Preventing intimate partner and sexual violence against women: taking action and generating evidence. Geneva: WHO; 2010; [cited 2018 apr 22]. Available from: https://www. who.int/reproductivehealth/publications/violence/9789241564007/en/

2. Sena CA, Silva MA, Falbo Neto GH. Incidência de violência sexual em crianças e adolescentes em Recife/Pernambuco no biênio 2012-2013. Ciênc Saúde Colet [Internet]. 2018; [cited 2018 may 10]; 23(5):15911599. Available from: http://www.scielo.br/scielo.php?script=sci_ arttext\&pid=S1413-81232018000501591\&Ing=pt\&nrm=iso\&tlng=en DOI: http://dx.doi.org/10.1590/1413-81232018235.18662016

3. Minayo MCS, Souza ER, Silva MMA, Assis SG. Institucionalização do tema da violência no SUS: Avanços e desafios. Ciênc Saúde Colet [Internet]. 2018 mar; [cited 2018 may 15]; 23(6):2007-16. Available from: http://cienciaesaudecoletiva.com.br/artigos/institucionalizacaodo-tema-da-violencia-no-sus-avancos-e-desafios/16686

4. Osis MJD, Duarte GA, Faúndes A. Violência entre usuárias de unidades de saúde: prevalência, perspectiva e conduta de gestores e profissionais. Rev Saúde Pública [Internet]. 2012 apr; [cited 2018 may 15]; 46(2):351-8. Available from: http://www.scielo.br/scielo. php?script=sci_arttext\&pid=S0034-89102012000200018\&lng=en\&nr m=iso DOI: http://dx.doi.org/10.1590/S0034-89102012005000019

5. Signorelli MC, Auad D, Pereira PPG. Violência doméstica contra mulheres e a atuação profissional na atenção primária à saúde: um estudo etnográfico em Matinhos. Cad Saúde Pública. 2013;29(6):12301240.

6. Vieira EM, Perdona GCS, Almeida AM, Nakano AM, Spano SMA Daltoso D, et al. Conhecimento e atitudes dos profissionais de saúde em relação à violência de gênero. Rev Bras Epidemiol [Internet]. 2009; [cited 2018 may 20]; 12(4):566-77. Available from: http://dx.doi.org/10.1590/ S1415-790X2009000400007

7. Ferrante FG, Santos MA, Vieira EM. Violência contra a mulher percepção dos médicos das unidades básicas de saúde da cidade de Ribeirão Preto, São Paulo. Interface (Botucatu) [Internet]. 2009 dec; [cited 2018 jun 05]; 13(31):287-299. Available from: http://dx.doi. org/10.1590/S1414-32832009000400005

8. Guedes RN, Fonseca RMGS, Egry EY. Limites e possibilidades avaliativas da estratégia saúde da família para a violência de gênero. Rev Esc Enferm USP [Internet]. 2013 apr; [cited 2018 jun 06]; 47(2):304311. Available from: http://www.scielo.br/scielo. php?script=sci arttext\&pid=S0080-62342013000200005\&lng=en\&nrm=iso DOI: http:// dx.doi.org/10.1590/S0080-62342013000200005

9. Presidência da República (BR). Casa Civil - Subchefia para Assuntos Jurídicos. Lei n. 12.845, de 1ำ de agosto de 2013. Dispõe sobre o atendimento obrigatório e integral de pessoas em situação de violência sexual. Brasília (DF): Presidência da República. 1 ago 2013; [cited 2018 jun 10]. Available from: http://www.planalto.gov.br/ccivil_03/_Ato20112014/2013/Lei/L12845.htm

10. Ministério da Saúde (BR). Ministério da Justiça, Secretaria de Políticas para as Mulheres. Norma Técnica Atenção Humanização às Pessoas em Situação de Violência Sexual com Registro de Informações e Coleta de Vestígios. Brasília (DF): Ministério da Saúde; 2015.

11. Santos ES, Almeida MAPT. Atendimento prestado pelos Serviços de saúde à Mulher Vítima de Violência Sexual. Id on Line Revista de Psicologia. 2017 apr; [cited 2018 jun 10]; 11(35):84-99. Available from: https://doi.org/10.14295/idonline.v11i35.721

12. Facuri CO, Fernandes AMS, Oliveira KD, Andrade TS, Azevedo RCS. Violência sexual: estudo descritivo sobre as vítimas e o atendimento em um serviço universitário de referência no Estado de São Paulo, Brasil. Cad Saúde Pública [Internet]. 2013 may; [cited 2018 jun 13]; 29(5):889-898. Available from: http://dx.doi.org/10.1590/S0102311 X2013000500008

13. Creswell, JW. Projeto de pesquisa: métodos qualitativo, quantitativo e misto. Porto Alegre: Artmed, 2007. 
14. Lansky S, Friche AAL, Silva AAM, Campos D, Bittencourt SDA, Carvalho $\mathrm{ML}$, et al. Pesquisa Nascer no Brasil: perfil da mortalidade neo-natal e avaliação da assistência à gestante e ao recém-nascido. Cad Saúde Pública [Internet]. 2014; [cited 2018 jul 04]; 30(Suppl 1):S192-S207. Available from: http://dx.doi.org/10.1590/0102-311X00133213

15. Spector JM, Agrawal P, Kodkany B, Lipsitz S, Lashoher A, Dziekan $G$, et al. Improving quality of care for maternal and newborn health: prospective pilot study of the WHO safe childbirth checklist program. PLoS One [Internet]. 2012 may; [cited 2018 jul 04]; 7(5):e35151. Available from: http://dx.doi.org/10.1371/journal.pone.0035151

16. Ministério da Saúde (BR). Secretaria de Políticas de Saúde. Política Nacional de Redução da Morbimortalidade por Acidentes e Violência. Rev Saúde Pública [Internet]. 2001 aug; [cited 2018 jul 11]; 34(4):427430. Available from: http://www.scielo.br/scielo.php?script=sci arttext\&pid=S0034-89102000000400020\&lng=en DOI: http://dx.doi. org/10.1590/S0034-89102000000400020

17. Garbin CAS, Dias IA, Rovida TAS, Garbin AJI. Desafıos do profıssional de saúde na notifıcação da violência: obrigatoriedade, efetivação e encaminhamento. Ciênc Saúde Coletiva [Internet]. 2015 jun; [cited 2018 jul 25]; 20(6):1879-1890. Available from: http://www.scielo.br/scielo. php?script=sci_arttext\&pid=S1413-81232015000601879\&lng=en\&n rm=iso DOI: $\mathrm{http}: / / d x$.doi.org/10.1590/1413-81232015206.13442014

18. Faúndes A, Rosas CF, Bedone AJ, Orozco LT. Violência sexual: procedimentos indicados e seus resultados no atendimento de urgência de mulheres vítimas de estupro. Rev Bras Ginecol Obstetr [Internet]. 2006 feb; [cited 2018 aug 01];28(2):126-135. Available from: http://dx.doi.org/10.1590/S0100-72032006000200009
19. Camilo LSS, et al. Preservação da cena de crime pelo enfermeiro no serviço de atendimento móvel de urgência: uma revisão integrativa. Cadernos de Graduação - Ciências Biológicas e da Saúde. 2017 Oct;4(2):185-202.

20. Mattar $\mathrm{R}$, et al. Assistência multiprofissional à vítima de violência sexual: a experiência da Universidade Federal de São Paulo. Cad Saúde Pública [Internet]. 2007 feb; [cited 2018 aug 01]; 23(2):459464. Available from: http://www.scielo.br/scielo.php?script=sci arttext\&pid=S0102-311X2007000200023\&lng=en\&nrm=iso DOl: http:// dx.doi.org/10.1590/S0102-311X2007000200023

21. Passos AIM, Gomes DAY, Gonçalves CLD. Perfil do atendimento de vítimas de violência sexual em Campinas. Rev Bioét [Internet] 2018 jan; [cited 2018 aug 02]; 26(1):67-76. Available from http://www.scielo.br/scielo.php?script=sci_arttext\&pid=S198380422018000100067\&lng=pt DOI: http://dx.doi.org/10.1590/198380422018261227

22. Waldow VR. Cuidado colaborativo em instituições de saúde: o enfermeiro como integrador. Texto Contexto - Enferm [Internet]. $2014 \mathrm{dec}$; [cited 2018 aug 07]; 23(4):1145-1152. Available from http://www.scielo.br/scielo.php?script=sci_arttext\&pid=S010407072014000401145\&lng=en DOI: http://dx.doi.org/10.1590/010407072014001840013

23. Cunha PLL. Implantação de cadeia de custódia de vestígios. Implicações para a gestão da polícia civil e do Distrito Federal [dissertation]. Brasília (DF): Escola de Administração Pública. Fundação Getúlio Vargas - FGV; 2012 